\title{
Development of Textbooks Based on Research in the Perspective of Education and Tourism Development in the Bukit Kangin Forest, Tenganan Pegringsingan
}

\author{
Nyoman Wijana $^{1, *}$ Sanusi Mulyadiharja ${ }^{1}$ \\ ${ }^{I}$ Biology Education Study Program, Universitas Pendidikan Ganesha, Singaraja, Indonesia \\ *Corresponding author. Email: nyoman.wijana@undiksha.ac.id
}

\begin{abstract}
Research has been carried out on the forest vegetation of Bukit Kangin and the results of the research are arranged in the form of a textbook. This book is designed to be used in from the perspective of education and forest tourism development. The purpose of this study was to determine the feasibility and practicality of using textbooks as teaching materials in the educational perspective of the Biology Education study program, FMIPA Undiksha and the perspective of developing forest tourism in the Tenganan Pegringsingan traditional village. The population of this study were (1) Lecturers of the Biology Education Study Program, Department of Marine Biology and Fisheries, FMIPA Undiksha, students, Lecturers of design experts, and the Tourism Awareness Group of the Tenganan Pegringsingan traditional village. The research sample amounted to 36 people. The location of the textbook product test was carried out in the classroom and in the Bukit Kangin forest, Tenganan Pegringsingan traditional village. The development of this textbook is designed to follow the ADDIE development model. The data collection method in this study used interviews, questionnaires, and literature studies. Data were analyzed descriptively quantitatively. The results showed that the book compiled as teaching materials used in the educational perspective of the Biology Education study program, FMIPA Undiksha and the perspective of developing forest tourism in the Tenganan Pegringsingan traditional village had very good feasibility and practicality values.
\end{abstract}

Keywords: Textbooks, Research-Based, Education, Forest Tourism.

\section{INTRODUCTION}

Tenganan Pegringsingan Village is one of the villages in Bali which has become a well-known destination throughout the universe. Already known by domestic and foreign tourists. In terms of tourism development in Bali, this tourist attraction is located in the East Bali tourist area. Tenganan Pegringsingan Village is one of the traditional villages of unique cultural tourism destinations that can be visited in the tour agenda to this area. This traditional village with its own uniqueness, which still maintains the customs and traditions inherited from their ancestors to this day. Various cultures that are used as tourism objects in the village of Tenganan Pegringsingan are the layout of the village and the environment that still follows the pattern of ancestral heritage that exists today, the architectural appearance of the building, the unique tradition of Mekare-kare (Megeret Pandan) or often known as Pandan War and Gringsing cloth [1].
When examined more deeply, it turns out that the village of Tenganan Pegringsingan has a lot of uniqueness and is very different from the villages in Bali in general. These uniquenesses include: [1].

The first is in the form of house construction rules. In the construction of houses carried out by the residents of Tenganan Pegringsingan village, they must follow the village awig-awig (traditional rules in the village). The construction of houses should not be carried out at will by the residents, because the land occupied by the residents is the right of the village. The size of the area occupied by residents is the same, the shape of the building must also be the same, the structure is similar, even the composition of the material is almost the same. In a yard there must be a "bale tengah" which has a jineng or rice barn on the top, a "bale beten" in the south and a kitchen and toilet on the west side.

The second uniqueness that needs to be considered is the marriage of citizens. There are binding customary rules for residents who are getting married, both for residents from the Tenganan Pegringsingan traditional 
village marrying residents from the Tenganan Pegringsingan traditional village itself and for Tenganan Pegrigsingan village residents who are married to residents from outside the Tenganan Pegringsingan village residents. The original residents from the Tenganan Pegringsingan traditional village who marry a Tenganan villager (marry a fellow villager) then they have the right to become villagers, but if they marry a resident from outside the village then they will be placed in Krame Bumi, to Banjar Pande which is in the east of the village Tenganan Pegringsingan, which has its own rice field outside the village.

The third uniqueness is the presence of wild buffalo in the middle of the village. Buffaloes in Tenganan Pegringsingan village are allowed to live freely in the middle of village settlements. These buffalo forage on plantations or in village fields, which are located around the village. Male buffalo are usually used for yadnya ceremonies, in religious ceremonies, the local village version. Before being used in the ceremony, it begins with a ceremony at the Kandang Temple which is located in the middle of the village of Tenganan Pegringsingan. After the ceremony, proceed with the slaughter. Buffalo that are old and die in the process of burial are carried out in a traditional ceremony procession, including when burying they must wear traditional clothes and carry a dagger.

There are many other unique things that exist in the village of Tenganan Pegringsingan which have not been revealed much in relation to cultural tourism. Some other uniqueness, for example there is no cremation ceremony, there are two setra (graves) with different designations, the existence of a sacred musical instrument called selonding, does not recognize polygamy, the position of girls, does not recognize caste, and sanggah gedebong (banana tree) which was made on during the ngusaba gedebong ceremony.

What is also interesting is the uniqueness in preserving the forest. Besides using the awig-awig reference, there are several unique conservation patterns, namely: ngalang, ngambeng, ngambang, ngerampag, penaho, pengapih and tumapung. These are local terms that exist in the local village which are principally an acknowledgment of granting rights to residents in forest management or forest use but have a very strict conservation concept.

This cultural-based tourism object is already quite well-known among tourists. However, one thing that needs to be developed is a forest tourism object. As is known, the village of Tenganan Pegringsingan has three hills, namely Bukit Kangin or Kangin Hill, Bukit Kauh or Kauh Hill, and Bukit Kaja or Kaja Hill. These three hills have been studied by the author. The studies that have been carried out by Wijana and colleagues are $[1][2][3][4][5][6][7][8][9][10]$. Several products have been published in the form of national, international journals, proceedings, and in the form of textbooks.

As an innovation in tourism development, forest tourism is an alternative that can be developed. The forest that can be developed as a tourist attraction is the Bukit Kangin forest, with considerations: the location is very close to the village, the vegetation is still beautiful, it doesn't take long for tourists to reach this object, can enjoy cultural tourism at the same time, the scenery is amazing when you are on a hill and the introduction of various plant species in the Bukit Kangin forest and their traditional uses. To support the development of forest tourism, a guide book on the introduction of plant species in the Bukit Kangin forest is needed.

The development of research-based textbooks was inspired by [11] Article 2 states that in achieving national education goals, it is recommended for teachers and students to use enrichment books. The use of this enrichment book is to add insight and knowledge of students in addition to using textbooks which are used as mandatory references. In addition, it is related to the procurement and utilization of enrichment books based on Minister of National Education Regulations No. 2 of 2008 in article 6 paragraphs 2 and 3, states that the use and procurement of enrichment books is highly recommended [12].

In learning biology in general and plant ecology in particular, one of the obstacles faced in field practice is the introduction of plant species in terms of their scientific names and taxon categories. In class learning, generally in the description of plant diversity, examples of plants that are commonly known are given, but conditions in the middle of the forest will be different in terms of identifying plant species. Therefore, practical guidance is needed in identifying plant species in the field, in this case in the Bukit Kangin forest in Tenganan Pegringsingan.

The results of research using supplementary textbooks in an educational perspective have succeeded in increasing mastery of material knowledge, increasing environmental awareness, and providing appreciation for local wisdom [5][6]. In addition, the use of textbooks for the community can be used as a guide in introducing the "content" of the forest in its development plan as forest tourism [9].

The design of this textbook contains an introduction to plant species in the Bukit Kangin forest. Thus, it is considered important to develop textbooks, based on research, so that they can be used in the perspective of education for academics and the development of forest tourism for the Tourism Awareness Group (Pokdarwis) of the Tenganan Pegringsingan traditional village. The purpose of this study was to determine the feasibility and practicality of using textbooks as teaching materials in the educational perspective of the Biology Education 
study program, FMIPA Undiksha and the perspective of developing forest tourism in the Tenganan Pegringsingan traditional village.

\section{METHOD}

This type of research is a development research type, namely the development of the preparation of a textbook of Useful Plants Based on Balinese Local Wisdom which is designed to be used by lecturers and students in an educational perspective in the Biology Education study program, FMIPA Undiksha and the Tourism Awareness Group (Pok Darwis) in the perspective of tourism development. forest in the traditional village of Tenganan Pegringsingan. The population of this study were Lecturers of the Biology Education Study Program, Department of Marine Biology and Fisheries, FMIPA Undiksha (14 people), Smester V students of the Biology Education Program, Department of Marine Biology and Fisheries, FMIPA Undiksha (2 classes), Lecturers of design experts from the Department of Technology and Education FIP Undiksha (2 people) and the Tourism Awareness Group of Tenganan Pegringsingan traditional village (25 people). The research samples were Plant Ecology Lecturers (1 person), colleagues with similar knowledge (1 person), design experts ( 1 person), 5 th grade students
(1 class) and the sample of the Tourism Awareness Group of Tenganan Pegringsingan traditional village (10 people) [13].

The location of the textbook product test was carried out in the classroom and in the Bukit Kangin forest, Tenganan Pegringsingan traditional village. The implementation of this research was before the Covid 19 pandemic so that it took place face-to-face. The development of this textbook is designed to follow the ADDIE development model [14] with the following chart.

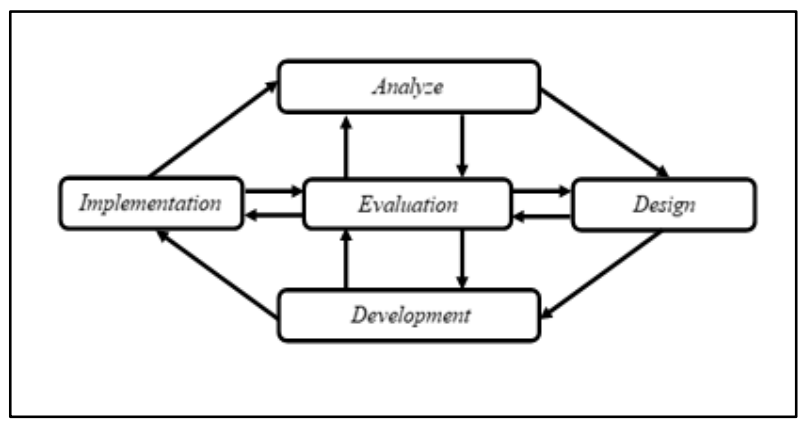

Figure 1 ADDIE Model Chart (Source: [14][15][16])

From the ADDIE model above, further steps of its work can be seen in Figure 1.

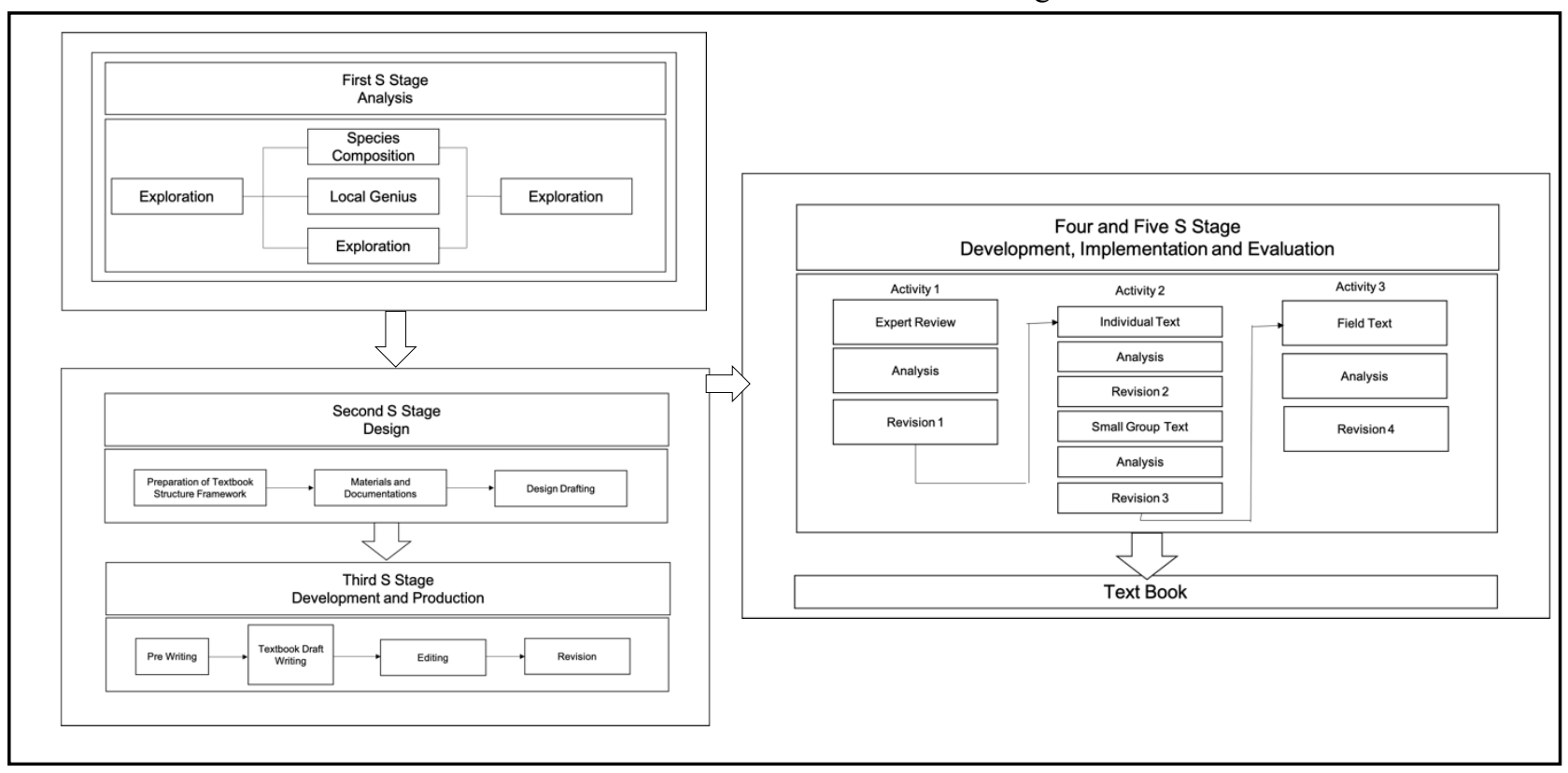

Figure 2 Chart of Preparation of Textbooks with the ADDIE Model

The data collection method in this study used interviews, questionnaires, and literature studies. Interviews and questionnaires were conducted for those involved in the book product test, both from academics (material experts, design experts, and students) and from the community, namely the Tourism Awareness Group (PokDarwis) in the Tenganan Pegringsingan traditional village. The instruments used for the feasibility assessment were material experts, design experts, and colleagues, students, and the Tourism Awareness Group (PokDarwis) using a lickert scale.

Some of the aspects assessed are 1. Aspects of the feasibility of the content of the indicators are (a) The suitability of the material with the needs analysis, (b) Accuracy of the material, (c) Up-to-date material, and 
(d) Encouraging curiosity. 2. Feasibility of presentation with indicators (a) Presentation of Learning, (b) Coherence and Coherence of Flow. 3. Language Feasibility with indicators (a) Straightforward, (b) Communicative, (c) Dialogical and Interactive, (d) Conformity with Language Rules. 4. Contextual Assessment Aspects with indicators (a) Contextual Nature, and (b) Contextual Component. The results of the feasibility test are then compared with the following criteria.

Table 1 Eligibility Assessment Criteria for Textbooks: Useful Plants Based on Balinese Local Wisdom

\begin{tabular}{|c|c|c|}
\hline $\begin{array}{c}\text { Level } \\
\text { Achievement } \\
(\%)\end{array}$ & Category & Information \\
\hline $85-100$ & Very worth it & No need for revision \\
\hline $65-84$ & Worthy & Revised as necessary \\
\hline $45-64$ & Decent enough & Quite a lot revised \\
\hline $0-44$ & Not worth it & Revised a lot \\
\hline
\end{tabular}

In a practical test of the use of textbooks in the field, by distributing questionnaires filled out by lecturers of Plant Ecology courses, fifth semester students taking Plant Ecology courses and community tourism awareness groups (PokDarwis). From the results of the questionnaire, the following steps were taken.

a. Do a complete recapitulation.

b. Scoring.

c. The scores that have been obtained are then converted using the conversion reference according to [17], as follows Equation (1).

Percentage $=\frac{(\Sigma \text { answer } \mathrm{x} \text { weight of each choice })}{n \times \text { higest weight }} \times 100 \%$

Refer to [17], to calculate the percentage of the overall subject used the formula in Equation (2):

Average percentage $=\frac{F}{N}$

The meaning of decision making on practicality data is presented in Table 2.

Table 2 Practical Assessment Criteria for Books: Useful Plants Based on Balinese Local Wisdom

\begin{tabular}{|l|l|}
\hline Percentage (\%) & Mean \\
\hline $81 \%-100 \%$ & Very practical \\
\hline $61 \%-.80 \%$ & Practical \\
\hline $41 \%-.60 \%$ & Practical enough \\
\hline $21 \%-40 \%$ & Not practical \\
\hline $0 \%-20 \%$ & Very impractical \\
\hline
\end{tabular}

(Source: [19])

\section{RESULTS AND DISCUSSION}

\subsection{Results}

\subsubsection{Analysis}

Book of Useful Plants Based on Balinese Local Wisdom is designed to contain the results of the author's own research at least the last five years. The content that is prioritized is the results of research on useful plants in Tenganan Pegringsingan Village for the 2019 and 2020 research years. With the analysis of the relevance of the research results in the last five years, the research results are used as content from the book Useful Plants Based on Local Wisdom Bali is:

Chapter I discusses the theoretical study of Balinese Local Wisdom, Chapter II on the Body Symbol Plants of Bali Aga Tenganan Pegringsingan Village, Karangasem, Chapter III on the Body Symbol Plants of Budakeling Village, Karangasem, Chapter IV on Medicinal Plants in the Monkey Forest Ubud Gianyar, Chapter V on Utilization of Endangered Plants in Sawan District, Buleleng, Chapter VI on Useful Plant Species and Their Mapping in the Tenganan Pegringsingan Forest, Karangasem Bali, Chapter VII on Utilization of Useful Plants and Their Products Socio-cultural Orientation Bali Aga Traditional Village Tenganan Pegringsingan Karangasem Bali, Chapter VIII on Mapping of Useful Plants in the Bukit Kangin Forest, Tenganan Pegringsingan Traditional Village, Karangasem, Bali, and Chapter IX describes the Benefits of Bamboo Plants in Tigawasa Village, Buleleng Bali. So in this book Useful Plants Based on Balinese Local Wisdom, several chapters related to the Bukit Kangin forest were tested on Biology Education Study Program students, FMIPA Undiksha and the indigenous village community of Tenganan Pegringsingan. The chapters that are relevant to the test of this textbook are Chapters I, II, VI, VII, and VIII.

In addition, the needs analysis can be seen from the internal side, namely the student's need for research data, which for the time being there have not been many books published nationally. On the one hand, reports on research results are mostly stored in closed rooms of the Institute for Research and Community Service or the centers of similar institutions. When students compose their final project, thesis, or dissertation, they really need data that can be scientifically justified. To fulfill that, this book is very much needed. From the external side, the traditional village community of Tenganan Pegringsingan really needs knowledge of the various types of plants that exist in the village which can be used for the purpose of introducing plant species to tourists visiting the Bukit Kangin forest, Tenganan Pegringsingan. Currently the development of forest tourism in the village of Tenganan Pegringsingan is being pioneered and developed. Thus, Tenganan 
Pegringsingan village which is used as the location of this research, this book can be used as a reference, especially in terms of the types of plants that exist in the village. So, this book can contribute to the needs of society.

For students who take courses related to vegetation, both in terms of vegetation analysis, conservation, systematic/taxonomy, phytogeography and others, this kind of book contributes greatly to be used as a reference source. This is due to the fact that this book has practical value in the field, not just a text book or theoretical setting, but contextual. It can be stated that the development of this book has practical, effective, and scientific values so that this book can be used as teaching material.

\subsubsection{Design}

The design of the book Useful Plants Based on Balinese Local Wisdom is entirely given to the publisher, who is already a professional, both regarding the cover, layout of the contents of the book, and others. However, the publisher also provides an opportunity for the author to provide corrections to the design and layout he made. In this case the author can discuss with design experts.

\subsubsection{Development}

This development stage aims to find out the opinions of material experts, response media experts from students, and colleagues. In this development stage, the author develops content to align with (1) the needs of students and (2) the needs of the tourism manager of the Tenganan Pegringsingan traditional village.

\subsubsection{Eligibility Validation}

The validation of the feasibility of the Useful Plants Based on Balinese Local Wisdom book is intended to obtain assessment, input, and development of this book from several experts including material experts, design experts, and practitioners. From this validation, it is hoped that this book can be further refined. Experts who act as validators in assessing the material from this book, including a lecturer from the Department of Biology and Marine Fisheries from the Faculty of Mathematics and Natural Sciences, Ganesha Education University, in particular from the Biology Education Study Program as well as teaching staff from the Biology study program. On the other hand, who is positioned as a design expert is one of the lecturers from the Department of Educational Technology from the Faculty of Education, Ganesha University of Education, and the feasibility validation is also carried out by practitioners, namely from one of the lecturers in the Biology Education Study Program and the Biology Study Program, FMIPA. Ganesha University of
Education which is also one of the teaching team for the Plant Ecology course.

\subsubsection{Material Expert Assessment}

The results of the validation of the feasibility of the material or content of this book involving Prof. Dr. Ida Bagus Putu Arnyana, M.Si, who holds the Plant Ecology course from the Department of Marine Biology and Fisheries from the Faculty of Mathematics and Natural Sciences (FMIPA), especially the Biology Education Study Program and at the same time as a lecturer at the Biology Study Program, Ganesha Education University

The results of the assessment from the Material Experts which consist of four aspects of the assessment, namely from the Feasibility Aspects of the content such as the Conformity of the Materials with Needs Analysis, Material Accuracy, Material Updates, and Encouraging Readers' Curiosity, the results obtained are $100 \%$. This score belongs to the very good category. In the aspect of Feasibility of Presentation with indicators of Presentation Techniques, Presentation Support, Learning Presentation, and Consistent and Consistent Flow, obtained a percentage of $100 \%$ which is included in the very good category. In the aspect of Language Feasibility with indicators of Straightforward, Communicative, Dialogical and Interactive, and Conformity with Language Rules, the percentage obtained is $90 \%$ which is included in the very good category. The average obtained from the four aspects is $97.5 \%$ which is included in the very good category.

The suggestions submitted by the material expert validator are: (1) the scientific names of a species should be written following the existing nomenclature rules. (2) There are a lot of typos, the writing is not relevant, and the pictures need to be sharpened (not blurry).

\subsubsection{Media Expert Rating}

The validation of the feasibility of the design and learning media was carried out by Dr. Nyoman Sudarma, M.Pd from the Department of Educational Technology, Faculty of Education (FIP) Ganesha University of Education. Data from the assessment results from the book design side with indicators of book size, cover design, and book content design are given a score of $100 \%$ which is included in the very good category. This book has been designed by a professional publisher. From a feasibility perspective to graphs or other supporting data (Tables, Figures, Schematics/Charts) the assessment results from media experts indicate that the supporting illustrations from this book are included in the very good category. This means that the illustrations in this book are relevant to 
the existing content. Not many suggestions are given by media expert validators.

\subsubsection{Peer Rating}

The results of the validation of the feasibility of the material or content of this book by colleagues can be stated that the results of the assessment from colleagues which consist of four aspects of the assessment, namely from the Feasibility Aspect of the content such as the Suitability of the Material with Needs Analysis, Accuracy of Material, Up-to-date Material, and Encouraging Reader's Curiosity. Yield of $100 \%$. This score belongs to the very good category. In the aspect of Feasibility of Presentation with indicators of Presentation Techniques, Presentation Support, Learning Presentation, and Consistent Flow, obtained a percentage of $100 \%$ which is included in the very good category. In the aspect of Language Feasibility with indicators of Straightforward, Communicative, Dialogical and Interactive, and Conformity with Language Rules, the percentage obtained is $100 \%$ which is included in the very good category. The average obtained from the four aspects is $100 \%$ which is included in the very good category.

\subsubsection{Student Assessment}

The results of the assessment by students are not much different from the results given by material experts, design experts, and colleagues. The aspects that are assessed are also the same, consisting of four aspects of the assessment, namely from the Feasibility Aspects of the content such as the Conformity of the Materials with Needs Analysis, Material Accuracy, Material Updates, and Encouraging Readers' Curiosity, the results obtained are $100 \%$. This score belongs to the very good category. In the aspect of Feasibility of Presentation with indicators of Presentation Techniques, Presentation Support, Learning Presentation, and consistent Flow, obtained a percentage of $100 \%$ which is included in the very good category. In the aspect of Language Feasibility with indicators of Straightforward, Communicative, Dialogical and Interactive, and Conformity with Language Rules, the percentage obtained is $100 \%$ which is included in the very good category. The average obtained from the four aspects is $100 \%$ which is included in the very good category.

\subsubsection{Assessment by Tourism Awareness Group (PokDarwis)}

The assessment conducted by the Tourism Awareness Group (PokDarwis) of the Tenganan Pegringsingan traditional village is intended to find out the feasibility of this textbook from their opinions which are used as a guide in the introduction of plant species in the Bukit Kangin forest of Tenganan Pegringsingan.
The results show that the Feasibility Aspects of the content such as the suitability of the material with the needs analysis, the accuracy of the material, the updating of the material, and encouraging reader's curiosity, the results obtained are $100 \%$. This score belongs to the very good category. In the aspect of Feasibility of Presentation with indicators of Presentation Techniques, Presentation Support, Learning Presentation, and Consistent Flow, obtained a percentage of $100 \%$ which is included in the very good category. In the aspect of Language Feasibility with indicators of Straightforward, Communicative, Dialogical and Interactive, and Conformity with Language Rules, the percentage obtained is $100 \%$ which is included in the very good category. The average obtained from the four aspects is $100 \%$ which is included in the very good category.

From the description above, further recapitulation of the results of the feasibility assessment from material experts, media experts, colleagues, students and tourism awareness groups (PokDarwis) can be made as presented in Table 3.

Table 3. Recapitulation of Textbook Feasibility Assessment Results: Useful Plants Based on Balinese Local Wisdom

\begin{tabular}{|c|l|c|}
\hline No & Validator & $\begin{array}{c}\text { Total } \\
\text { Percentage }\end{array}$ \\
\hline 1 & Material Expert & $97,5 \%$ \\
\hline 2 & Media Expert & $100 \%$ \\
\hline 3 & Peers & $100 \%$ \\
\hline 4 & Student & $100 \%$ \\
\hline 5 & $\begin{array}{l}\text { Tourism Awareness } \\
\text { Group (PokDarwis) }\end{array}$ & $100 \%$ \\
\hline Average & $99,50 \%$ \\
\hline Criteria & Very Good \\
\hline
\end{tabular}

Based on Table 1.3. from the assessment by two experts and one colleague, students and the tourism awareness group (PokDarwis) obtained an average of $99.50 \%$ which is included in the very good category. This means that this book is very suitable to be used as a teaching material, field reference material, or as a guide for field work and other developments.

\subsubsection{Implementation}

In this implementation test, it is intended to find the practical value of using this textbook in the field. In this field test, it was carried out by lecturers, students and also by the Tourism Awareness Group (PokDarwis) group of the Tenganan Pegringsingan traditional village. In the implementation of the book Useful Plants Based on Balinese Local Wisdom, it was carried out in several stages, starting from a small group test, consisting of a 
test for lecturers who taught Plant Ecology, students who had taken Plant Ecology courses and the Tourism Awareness Group (PokDarwis) in the Tenganan Pegringsingan traditional village. Next, a large group test was conducted, namely Semester V class A students, who took the Plant Ecology course. Field trials were also conducted on the Tourism Awareness Group (PokDarwis) of the Tenganan Pegringsingan traditional village.

\subsubsection{Small Group Trial (Semester VII Students)}

Practical trials in small groups were carried out by involving 5 students who had taken Plant Ecology courses, namely in the seventh semester. While the Plant Ecology course appeared in semester V. The results of practicality tests by small groups showed that the practicality of the book on Useful Plants Based on Balinese Local Wisdom according to students showed that the book had a very practical value with an average percentage of $97.5 \%$. This means that the book on Useful Plants Based on Balinese Local Wisdom can be practically used in the field as a reference in the practice of Plant Ecology courses. The book has been equipped with pictures of real plants in the field, mapping distribution of plant species, and equipped with taxonomic categories and descriptions of plant species which include habitus, tree height, stem morphology, leaves, flowers, fruits, and others. In principle can describe plant species found in the field.

\subsubsection{Small Group Test by Tourism Awareness Group (PokDarwis)}

This small group test was also carried out on two Tourism Awareness Group (PokDarwis) in the Tenganan Pegringsingan traditional village. The results show that the practicality value given by the tourism awareness Group (PokDarwis) is $100 \%$. This means that this textbook can be used practically in the introduction of plant species in the field or in the Bukit Kangin forest.

\subsubsection{Small Group Test by Lecturer of Plant Ecology}

It should be said that the teaching of Plant Ecology is carried out in a team, namely the author himself and one team, namely Prof. Dr. Ida Bagus Putu Arnyana, M.Si. Furthermore, the lecturer friend was asked for his help in trying to use the book Useful Plants Based on Balinese Local Wisdom as teaching material for enrichment in the topic of conservation and analysis of plant diversity. From the results of these trials, the results of the assessment gave a value of $92.5 \%$ which was in the very practical category. Descriptively it was conveyed that the book of Useful Plants Based on Balinese Local Wisdom has very practical value for use in the field. In teaching Plant Ecology on the topic of conservation and diversity, it is very relevant to be used as reference material. In giving assignments to students related to plant diversity in the traditional village of Tenganan Pegringsingan, students were greatly helped by this book in introducing plant species. Likewise, related to conservation, this book has listed cultural matters of the Tenganan Pegringsingan traditional village community so that students can easily get examples of patterns from books and can develop them further. From the data from the assessment by the small group test of students, lecturers and the Tourism Awareness group (PokDarwis), then the average value was sought. The results of the mean values of the three small groups are presented in Table 4. Based on Table 4 , it can be seen that the average assessment result of the three small groups obtained a score of $96.5 \%$ which is included in the very practical category. So based on the three assessors from the small group, in general they stated that this book was very practical to use as a textbook and field guide in the introduction of plant species in the Bukit Kangin forest.

Table 4 Average Results of Small Group Practicality Tests Textbooks of Useful Plants Based on Balinese Local Wisdom

\begin{tabular}{|c|c|c|}
\hline No & Validator & Percentage \\
\hline 1 & Student Small Group & $97.5 \%$ \\
\hline 2 & Small Group Test & $92.5 \%$ \\
\hline 3 & SmallTourism & $100 \%$ \\
\hline \multicolumn{2}{|c|}{ Average } & $96.5 \%$ \\
\hline & Criteria & Very Practical \\
\hline
\end{tabular}

\subsubsection{Large Group Field Test}

The intended field test is the use of Useful Plants Books Based on Balinese Local Wisdom as teaching materials for students taking the Plant Ecology course, namely students in semester V. As a trial, it is carried out in class A. It should be stated that in semester V there are two classes, namely class A and class B. There are 13 students in total. From the test results obtained data that the average result of the large group trial is $97.5 \%$ which is included in the very practical category. This means that the book of Useful Plants Based on Balinese Local Wisdom can be used as teaching material in the Plant Ecology course. The practical value is especially when students are given field assignments in the Tenganan Pegringsingan traditional village in the book to analyze the topic of vegetation and conservation based on local wisdom.

For the large group test on the tourism awareness group (PokDarwis) in the Tenganan Pegringsingan traditional village by taking a sample of 10 people, the 
overall results from the tourism awareness group (PokDarwis) gave a maximum value of $100 \%$. From their statements in personal interviews, they said that this book could indeed be used to introduce plant species in the Bukit Kangin forest. In identifying plant species, they are familiar and already know the plant. In other words, they are already familiar with the plants in the forest. The "weirdness" they convey is the scientific names of these plants. They do not know the scientific names of these plants. Thus, they use the local name as it is also in the book. The two large group tests can then be summarized as follows in Table 5 .

Table 5 Average Results of Practical Test Assessment of Large Groups of Useful Plants Textbooks Based on Balinese Local Wisdom

\begin{tabular}{|c|l|c|}
\hline No & Validator & Percentage \\
\hline 1 & Student Large Group & $97.5 \%$ \\
\hline 2 & $\begin{array}{l}\text { Large Group Tourism } \\
\text { Awareness }\end{array}$ & $100 \%$ \\
\hline \multicolumn{2}{|c|}{ Average } & $98.5 \%$ \\
\hline \multicolumn{2}{|c|}{ Criteria } & Very Practical \\
\hline
\end{tabular}

\subsubsection{Evaluation}

The last ADDIE development stage is the evaluation stage or the assessment stage. After carrying out the implementation stage, the next stage enters the assessment stage of the Bali Local Wisdom-Based Useful Plants book. At the evaluation stage, the evaluation of the results of the feasibility validation involved small group tests of students, small group tests of lecturers and teaching teams, small group tests of dervishes, and tests of large groups of students and large groups of dervishes and large group tests of dervishes as a whole showed the results. Which is included in the very good category. Therefore, in this evaluation stage, it can be interpreted that the book of Useful Plants Based on Balinese Local Wisdom has very good feasibility and practicality. Similarly, based on the suggestion previously made, this book is appropriate to be followed up as a supplement to teaching materials and a guide to species introduction.

\subsubsection{Product revision}

There are not many product revisions from material experts and design experts. Although there are suggestions from material experts, it includes minor revisions and revisions have been made in terms of improving species names, corrections to writing, and several other important matters. Further corrections will be made by the Editor of the Publishing Graha Ilmu Yogyakarta. The final result of the book that has been published by Graha Ilmu Yogyakarta can be seen in Figure 3.
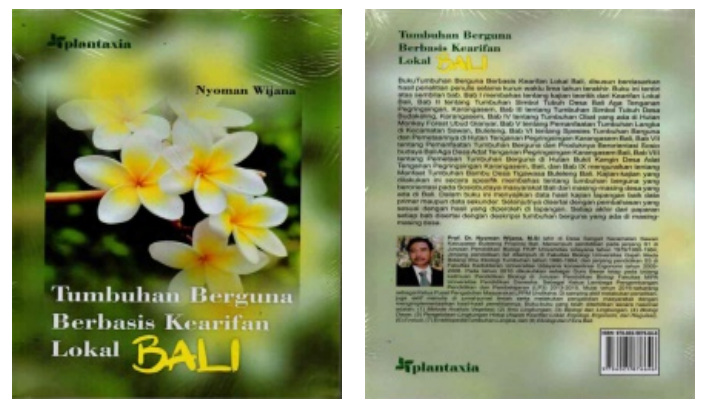

Figure 3. Book Product: Useful Plants Based on Balinese Local Wisdom

\subsection{Discussion}

Based on [11] Article 2 states that in achieving national education goals, it is recommended for teachers and students to use enrichment books. The use of this enrichment book is to add insight and knowledge of students in addition to using textbooks which are used as mandatory references. In addition, it is related to the procurement and utilization of enrichment books based on National Education Regulation No. 2 of 2008 in article 6 paragraphs 2 and 3 , states that the use and procurement of enrichment books is highly recommended [12].

The supplementary book for teaching materials based on its function is an enrichment book in learning. Teaching material supplement book contains material or information that serves to complement the material in the main book, in the sense that the teaching material supplement book is to support the material in the main book. This supplementary book of teaching materials is not required to be owned by students and teachers, but it is very useful in broadening students' insight and understanding related to the knowledge obtained from the main book. This is because in an enrichment book a subject is discussed in more depth and its preparation does not fully refer to the curriculum, seen from the objectives and subject matter, as well as in the method of presentation [17]

According to [18] stated that the process of testing the feasibility of a supplementary assessment book can be carried out by any expert related to the material contained in the book, so that it is in line with the material and design of teaching materials developed, so that weaknesses and strengths can be identified. According to [19] said that teaching materials can be said to be feasible if the percentage of assessment is between $65 \%$ to d. $84 \%$ so that necessary revisions are needed. Meanwhile, teaching materials can be said to be very feasible if the percentage of assessment is between $85 \%$ to d. $100 \%$ so there is no need to revise again. Revisions are made based on input from experts during a feasibility test, so that the product developed can be used as a supplement to teaching materials in the learning process. The results of this feasibility test are in 
accordance with the research reported by [20] that development research in the form of supplements of biology teaching materials based on community local wisdom is categorized as very feasible to be applied in the Biology learning process at the high school level.

According to [21] which states that the readability of teaching material supplements is an attraction for readers to study textbook supplements, making it easier to learn materials related to learning objectives and the ease of language used in textbook supplements to be understood by users. Furthermore, [21] reports that based on his research, it shows that supplementary textbooks based on local wisdom are very suitable for use in learning.

According to [22] states that the function of the findings or research-based in learning can increase students' knowledge and be able to improve the quality of learning. In addition, the development of supplementary teaching materials accompanied by linking the materials with local wisdom of the community makes these teaching materials more interesting and contextual. On the other hand, according to [23] stated that material related to everyday life phenomena is a good way to study conservation and can better understand in analyzing the conditions of the surrounding environment. According to [24] states that it is necessary to emphasize local wisdom as a material in biology learning. Utilization of local wisdom content can help students learn biology with real learning applications.

According to [5] report that research results can be implemented in learning as the development of teaching materials in the classroom. In this case, the results of research on rare plants in Sudaji Village, Sawan District, Buleleng Regency can be implemented in a lecture on Plant Ecology. Furthermore, according to [6] reported that there was an increase in student soft skills in integrating local wisdom-oriented character education into teaching materials for Environmental Science courses.

According to [25] reports that the development of biology teaching materials based on local Timorese wisdom can improve students' knowledge and attitudes about the environment. Other experts convey the results of their research such as [26] stating that the use of learning resources such as encyclopedias will affect student learning outcomes. According to [27] states that if teachers use visual aids, students will learn more effectively because the things that have been seen will give the impression of a clearer vision, easy to remember, and easy to understand. This book does not only display material in written form, but also in the form of images so that students can easily grasp the meaning of the available descriptions. Encyclopedias can be used as alternative learning resources that are used to provide accurate and up-to-date information and can broaden their horizons for their readers [28].

According to [29] revealed that with the preparation of teaching materials based on research results, accurate, up-to-date and sustainable information and data will be obtained. This book can add insight to students because it is in line with the results of [30] showing that an increase in research-based development has led to a strengthening in the quality of learning, and triggered changes in increasing the space for student involvement.

The research that shows that the encyclopedia can be an effective supplement for teaching materials is the research of [31] which states that the Encyclopedia of Medicinal Plants collection by PT. Sidomuncul is a supplement to support student learning so that when combined with other learning resources and appropriate worksheets, it can facilitate the achievement of basic competencies.

\section{CONCLUSION}

From the results of this study, it can be concluded that the book compiled as teaching material used in the educational perspective in the Biology Education study program, FMIPA Undiksha and the perspective of developing forest tourism in the Tenganan Pegringsingan traditional village has very good feasibility and practicality values. The feasibility score given by material experts, design experts, and peers is an average of $99.16 \%$. The practical value given by a small group of students, a small group of Lecturers of the Teaching Team, and a small group of Dervishes is an average of $96.5 \%$. The practicality value for the large group test of the large group of students and the large group of the Tourism Awareness Group averaged $98.5 \%$. Suggestions that can be conveyed from the conclusions of this study are that the use of textbooks as teaching materials is based on research-based textbooks. The studies that have been carried out by researchers should be arranged in the form of textbooks so that they can be used as teaching materials.

\section{REFERENCES}

[1] N. Wijana and I. Setiawan, "Pemetaan dan Distribusi Tumbuhan Berguna, Upaya Pelestarian dan Rancangan Pengembangan Hutan Adat sebagai Obyek Wisata Kreatif di Hutan Adat Bali Age Tenganan Pegringsingan, Propinsi Bali," 2019.

[2] N. Wijana and I. N. Sumardika, "Pelestarian Jenis-Jenis Tumbuhan berguna Melalui Kearifan Lokal di Desa Adat Tenganan Pegringsingan, Kabupaten Karangasem, Bali. Dimuat dalam prosiding Konservasi Flora Indonesia dalam Mengatasi Dampak Pemanasan Global.," Kebun Raya “Eka Karya - LIPI, pp. 724-731, 2009, 
[Online]. Available: ISBN 978-979-799-447-1.

[3] N. Wijana and I. Setiawan, "Pemetaan Pencaran dan Pola Sebaran Spesies Tumbuhan Langka serta Upaya Pengelolaan Berbasis Kearifan Lokal pada Hutan Wisata di Provinsi Bali.," Lap. Penelitian., 2017.

[4] N. Wijana, P. I. Rahmawati, I. G. A. N. Setiawan, and S. Mulyadiharaja, "Plants of Body Symbols in Tri Mandala Tenganan Pegringsingan Village, Karangasem (in Ethnobotany Learning Perspective).," Int. J. Nat. Sci. Eng., vol. 3, no. 1, pp. 1-11, 2019.

[5] N. Wijana, I. G. A. N. Setiawan, and S. Mulyadiharja, "Exploration of Rare Plant Species in the Sudaji Village of Sawan District, Regency of Buleleng, Bali and Implementation in Learning Model," J. Eng. Appl. Sci., vol. 15, no. b, pp. 1943-1950, 2020.

[6] N. Wijana, . "Pengaruh Pengintegrasian Pendidikan Karakter Berorientasi Kearifan Lokal Ke Dalam Materi Ajar Mata Kuliah Ilmu Lingkungan Untuk Meningkatkan Soft Skill Mahasiswa Jurusan Pendidikan Biologi Fmipa Undiksha.," J. Pendidik. Indones. | 647. ISSN 2303-288X, vol. 4, no. 2, 2015.

[7] N. Wijana and S. Mulyadiharja, "Pengaruh Penggunaan Pendekatan Ergologi Dalam Pengimplementasian Pendidikan Karakter ke Dalam Praktek Kerja Lapangan Dalam Mata Kuliah Ekologi Tumbuhan untuk Meningkatkan Nilai Karakter Mahasiswa Jurusan Pendidikan Biologi FMIPA Undiksha," 2018.

[8] N. Wijana and I. Setiawan, "Pengintegrasian Pendidikan Karakter Berorientasi Kearifan Lokal ke Dalam Materi Ajar Mata Kuliah Ilmu Lingkungan untuk Meningkatkan Soft Skill Mahasiswa Jurusan Pendidikan Biologi FMIPA," 2014.

[9] N. Wijana and S. Mulyadiharaja, "Sosialisasi dan pendampingan: hasil riset flora dan pemetaan distribusi spesies tumbuhan dalam menunjang pariwisata desa Wanagiri, Buleleng (Suatu Pemberdayaan Pemanfaatan Sumber Daya Alam dan Peningkatan Kualitas Sumber Daya Manusia).," Makalah diseminarkan pada Seminar Nasioal Pengabdian Pada Masyarakat 16 Maret 2021 di kampus Universitas Pendidikan Ganesha., 2021.

[10] N. Wijana, Ekologi dan Flora Bali. Yogyakarta: Plantaxia, 2018.

[11] "Peraturan Menteri Pendidikan Nasional Republik Indonesia No. 11 Tahun 2005 Tentang Buku Teks Pelajaran."

[12] Suherli, Buku Teks Layak Pakai di Sekolah. 2008.
[13] J. W. Best, Metodologi Penelitian Pendidikan. Surabaya: Usaha Nasonal, 1982.

[14] W. Dick and Carey, The Systematic design of Instruction, 3rd edition USA. Harper Cllins, 1990.

[15] I. M. Tegeh, I. N. Jampel, and P. K, Model Penelitian Pengembangan. Yogyakarta: Graha Ilmu, 2014.

[16] I. M. Tegeh and I. M. Kirna, Metode Penelitian Pengembangan Pendidikan. Singaraja: Universitas Pendidikan Ganesha, 2014.

[17] Sitepu, Penulisan Buku Teks Pelajaran. Bandung: Remaja Rosdakarya, 2012.

[18] Sugyono, Metode Penelitian Pendidikan (Pendekatan Kuantitatif, Kualitatif dan R\&D. Bandung: CV Alfabeta, 2015.

[19] W. Wulandari, "Pengembangan Suplemen Bahan Ajar Biologi Berbasis Riset Identifikasi Bakteri untuk Siswa SMA.," J. Innov. Sci. Educ. p-ISSN 2252-6412 e-ISSN 2502-4523.

[20] Nuha and I. Watun, "Pengembangan Buku Suplemen Biologi Berbasis Kearifan Lokal Kabupaten Pati Sebagai Penunjang Materi Keanekaragaman Hayati Kelas X Sma/Ma," Universitas Islam Negeri Walisongo Semarang, 2017.

[21] H. Reski, "Pengembangan Suplemen Buku Ajar Berbasis Kearifan Lokal Pada Materi Biosintesis Eikosanoid," J. Progr. Stud. Pendidik. Kim. FKIP Untan.

[22] Hafsah, "Implementasi Riset Based Learning dalam Upaya Peningkatan Kualitas Pembelajaran," Universitas Negeri Padang., 2015.

[23] A. S. Leksono and P. Marianingsih, "Pengembangan Bahan Ajar Biologi Konservasi Berbasis Etnopedagogi," J. Kependidikan, vol. 45, no. 2, pp. 168-183, 2015.

[24] M. Ramli, Analisis Substansi Pendidikan Mutikultural Sains di Buku Pelajaran Biologi untuk SMA. Surakarta: UNS, 2013.

[25] A. S. Ardan, "The Development of Biology Tecahing Material Based on The Local Wisdom of Timoreses to Improve Students Knowledge and Attitude of Environment In Caring the Persevation of Environment.," Int. J. High. Educ., vol. 5, no. 3, 2016.

[26] H. Susana, "Studi Deskriptif Tentang Pemanfaatan Perpustakaan Sekolah sebagai Sumber Belajar dan Hubungannya Dengan Prestasi Peserta didik Kelas V SD Pangudi Luhur Bernardus Semarang Tahun Pelajaran 2004/2005," Semarang:Unnes, 2005. 
[27] O. Hamalik, Perencanaan Pengajaran Berdasarkan Pendekatan Sistem. Jakarta: PT Bumi Aksara, 2009.

[28] G. Vanessa, "Pembuatan Ensiklopedia Hewan Punah dan Terancam Punah Berbasis Web. Caliptra," J. Ilm. Mahapeserta didik Univ. Surabaya, 2013.

[29] S. Handayani, "Pengembangan Modul Pembelajaran Berbasis Pengujian di Laboratorium sebagai Upaya Peningkatan Kompetensi," Universitas Pendidikan Indonesia, Bandung, 2014.

[30] I. Yahya, "Manajemen Empat Langkah dalam Pengembangan Bahan Ajar Berbasis Riset: Sebuah Pengalaman dari Perkuliahan Akustik di Jurusan Fisika FMIPA UNS.”

[31] S. Nizar, Y. U. A, and R. Susanti, "Pengembangan Ensiklopedia Tanaman Obat Koleksi PT Sidomuncul Sebagai Media Pembelajaran Materi Plantae Kelas X SMA," $J$. Biol. Educ., vol. 6, no. 1, pp. 11-18, 2017. 